\title{
GENETICS OF COLD TOLERANCE IN MAIZE AND SWEET CORN SEED
}

\author{
GORDON HASKELL \\ Jahn Innes Horticultural Institution, \\ Bayfardbury, Hertford, Herts.
}

Received 29.i.52

THERE are several important factors influencing the adaptation and establishment of sweet corn as a horticultural crop in England and other European countries. As conditions in England at sowing times are colder and wetter than those for which varieties have been selected under American conditions (Mather and Haskell, 1949), ability of seeds to germinate in moist or wet soil at low temperatures is very important. A recent preliminary survey of the germination of hybrid dent corn from Iowa and Minnesota grown at Bayfordbury made it clear that use of American strains, unselected for specific English conditions, was also limited by poor germination. This has renewed interest in the problem of maize germination at low temperatures.

There have been numerous studies on cold testing of maize under unfavourable conditions to determine the factors preventing germination. Wernham ( $195 \mathrm{I}$ ) has reviewed these investigations in detail. Only genetical aspects will here be considered, based on results from a study of reciprocal crosses between inbred sweet and dent maize. The aim is to evaluate maternal influence, endosperm and pericarp effects and the role of hybrid vigour.

Literature Review. Reciprocal differences are known. Smith (1935) found that an inbred maize resistant to Gibberella zeae crossed with a susceptible gave $F_{1}$ hybrids as resistant as the resistant parental inbred; there was strong indication that (susceptible $\times$ resistant) was more susceptible than (resistant $\times$ susceptible). Pinnell (1949) also found strong maternal influence on seedling emergence in cold tests of reciprocal crosses between inbred dent lines. Mortimore (in Wernham, 1951) showed significant differences in germination between reciprocals of high and low germinating inbreds: the maternal parent was more important in determining differences. Rush (in Wernham, I95I) considered embryo constitution unimportant because embryos in reciprocal crosses are identical. He suggested that pericarp and/or endosperm are important.

Inbreds may differ from their hybrids in cold tolerance. Thus Haskell and Singleton (1949) believed that heterosis usually shows its effects in cold tests of inbred and hybrid dent maize by improved germination of the hybrids. They interpreted a reverse instance as due to negative heterosis. On the other hand, Rossman (1949) considered 
that freezing tolerance of the seed is not a manifestation of hybrid vigour, maternal seed characteristics being more important than embryo constitution.

\section{EXPERIMENTAL METHODS}

The seeds investigated were from hand pollinations of inbred strains grown at New Haven, Conn., in 1947, viability still being satisfactory. The material included Conn 520 , a starchy dent $(S u)$ maize inbred; four sweet corn $(s u)$ inbreds, viz. $\mathrm{C}_{4}, \mathrm{C}_{40}, \mathrm{~T}_{5} \mathrm{I}$ and $\mathrm{C}_{95}$; reciprocal hybrids between the sweets and dent, and a few sweet hybrids. The pedigrees are given in table $\mathbf{I}$.

TABLE I

Germination of Sweet Corn Inbreds and a Dent Maize Inbred and their Reciprocal Hybrids after

Treatment for to days at $50^{\circ} \mathrm{F}$. (Based on 50 seeds per box except those marked $\dagger$.)

\begin{tabular}{|c|c|c|c|c|c|c|c|}
\hline \multirow{2}{*}{ No. } & \multirow{2}{*}{$\begin{array}{c}\text { Pedigree } \\
\text { No. }\end{array}$} & \multirow{2}{*}{ Parentage } & \multirow{2}{*}{$\begin{array}{l}\text { Inbred } \\
\text { or } \\
\text { Hybrid }\end{array}$} & \multirow{2}{*}{$\begin{array}{l}\text { Genotype } \\
\text { Endosperm }\end{array}$} & \multicolumn{3}{|c|}{$\%$ Germination } \\
\hline & & & & & Plot I & Plot 2 & Mean \\
\hline I & 859 selfed & Conn 520 & I & $\mathrm{Su} / \mathrm{Su} / \mathrm{Su}$ & 90 & 96 & 93.0 \\
\hline 2 & 820 selfed & $\mathrm{C}_{4}$ & I & $\mathrm{su} / \mathrm{su} / \mathrm{su}$ & 48 & 74 & $6 I \cdot 0$ \\
\hline 3 & $859 \times 820$ & Conn $520 \times \mathrm{C}_{4}$ & $\mathrm{H}$ & $\mathrm{Su} / \mathrm{Su} / \mathrm{su}$ & 88 & 96 & $92 \cdot 0$ \\
\hline 4 & $859 \times 807$ & Conn $520 \times \mathrm{C}_{4}$ & $\mathrm{H}$ & $\mathrm{Su} / \mathrm{Su} / \mathrm{su}$ & 52 & 90 & $Y I \cdot O$ \\
\hline 5 & $807 \times 859$ & $\mathrm{C}_{4} \times$ Conn 520 & $\mathrm{H}$ & $\mathrm{su} / \mathrm{su} / \mathrm{Su}$ & $84^{\dagger}$ & $96 \dagger$ & $90 \cdot 0$ \\
\hline 6 & $8_{30}$ selfed & $\mathrm{C}_{40}$ & I & $\mathrm{su} / \mathrm{su} / \mathrm{su}$ & 46 & 74 & $60 \cdot 0$ \\
\hline 7 & $859 \times 830$ & Conn $520 \times \mathrm{C}_{40}$ \} & $\mathrm{H}$ & $\mathrm{Su} / \mathrm{Su} / \mathrm{su}$ & 80 & 100 & $90 \cdot 0$ \\
\hline 8 & $830 \times 859$ & C $40 \times$ Conn 520$\}$ & $\mathrm{H}$ & $\mathrm{su} / \mathrm{su} / \mathrm{Su}$ & $4^{8}$ & $9^{2}$ & $70 \cdot 0$ \\
\hline 9 & 850 selfed & $T_{51}$ & I & $\mathrm{su} / \mathrm{su} / \mathrm{su}$ & $45 \dagger$ & 6 ot & $52 \cdot 5$ \\
\hline 10 & $859 \times 850$ & Conn $5^{20} \times \mathrm{T}_{51}$ & $\mathrm{H}$ & $\mathrm{Su} / \mathrm{Su} / \mathrm{su}$ & 100 & 96 & $98 \cdot 0$ \\
\hline II & $850 \times 859$ & $\left.\mathrm{~T}_{51} \times \operatorname{Conn} 520\right\}$ & $\mathrm{H}$ & $\mathrm{su} / \mathrm{su} / \mathrm{Su}$ & 16 & 76 & $4^{6 \cdot 0}$ \\
\hline 12 & $86 ̆ 9$ selfed & C95 & I & $\mathrm{su} / \mathrm{su} / \mathrm{su}$ & 0 & 5 & $2 \cdot 5$ \\
\hline 13 & $859 \times 869$ & Conn $520 \times \mathrm{C}_{95}$ & $\mathrm{H}$ & $\mathrm{Su} / \mathrm{Su} / \mathrm{su}$ & 76 & 94 & 85.0 \\
\hline 14 & $869 \times 859$ & C95 $\times$ Conn 520$\}$ & $\mathrm{H}$ & $\mathrm{su} / \mathrm{su} / \mathrm{Su}$ & 40 & $84 \dagger$ & $62 \cdot 0$ \\
\hline 15 & $850 \times 830$ & $\mathrm{~T}_{5} \mathrm{I} \times \mathrm{C}_{40} \mathrm{O}$ & $\mathrm{H}$ & $\mathrm{su} / \mathrm{su} / \mathrm{su}$ & 8 & 24 & $16 \cdot 0$ \\
\hline 16 & $830 \times 850$ & $\left.\mathrm{C}_{40} \times \mathrm{T}_{5} \mathrm{x}\right)$ & $\mathrm{H}$ & $\mathrm{su} / \mathrm{su} / \mathrm{su}$ & 12 & 60 & $36 \cdot o$ \\
\hline 17 & $820 \times 830$ & $\left.\mathrm{C}_{4} \times \mathrm{C}_{40}\right\}$ & $\mathrm{H}$ & $\mathrm{su} / \mathrm{su} / \mathrm{su}$ & go† & roo† & $95 \cdot 0$ \\
\hline
\end{tabular}

Two lots of fifty seeds of each were sown in seed boxes on 3 rd April 195I. Unsterilised field soil, on which maize had previously grown, was used. The boxes were placed at random in two plots in the controlled temperature room. The soil was evenly watered each day to keep it moist. Seed boxes were transferred to a warm greenhouse after Io days at $50^{\circ} \mathrm{F}$., and records made of germinations (Haskell, I949). Final percentage germinations were calculated and then transformed to angles for the analysis of variance. These data are also given in table I. The wet weights of seedlings were also determined on ist May, i.e. 18 days after transference to warmth.

\section{EFFECTS OF TREATMENT}

(i) Differences in Cold Tolerance. The analysis of variance given in table 2 shows that the strains genuinely differ in ability to germinate following low temperature treatment. There is also a highly significant difference between plots; this could partly be accounted for by overhead illumination in the controlled temperature room being nearer to 
one plot. This might have created a local rise of temperature, but more likely it promoted convection currents, thus drying out soil faster

TABLE 2

Analysis of Variance of Cold Tolerance Data

\begin{tabular}{|c|c|c|c|c|c|c|}
\hline \multirow{8}{*}{$\begin{array}{l}\quad \text { Stem } \\
\text { Lines } \\
\text { Inbreds v. Hybrids } \\
\text { Su-su Reciprocals } \\
\text { Remainder } \\
\text { Plots } \\
\text { Line-Plots (Error) }\end{array}$} & \multicolumn{6}{|c|}{ Germinations transiormea } \\
\hline & S. S. & $\mathrm{N}$ & M.S. & V.R. & $t$ & $\mathbf{P}$ \\
\hline & $14,55^{2} \cdot 5^{I}$ & 16 & 909.53 & I $3 \cdot 65$ & - & $>0.001$ \\
\hline & $\mathrm{I}, 4^{8} 7 \cdot 20$ & I & $1487^{\circ}$ & - & $4 \cdot 73$ & $>0.00 I$ \\
\hline & 957.90 & I & $957^{\circ}$ & - & 3.79 & $0.01-0.0$ \\
\hline & $12,107.4$ & I4 & $864^{\circ}+7$ & I 2.99 & & $>0.00 \mathrm{I}$ \\
\hline & $2,523 \cdot 50$ & I & 2523.50 & - & $6 \cdot 15$ & $>0.001$ \\
\hline & & I 6 & 66.59 & & & \\
\hline Total & I $8,14 \mathrm{I} \cdot 47$ & & & & & \\
\hline
\end{tabular}

in the seed boxes adjacent to the lights. These boxes would then have better germinations, as their soil would be drier and pathogens would have less opportunity of acting on the seeds. The use of means of the two plots in later calculations reduces error due to plot differences.

There are significant differences in cold tolerance between inbreds and all their hybrids, when the item for the numerous lines is broken down into its components. Thus hybrid vigour is important. The mean square for reciprocal dent-sweet crosses is less than that for hybrid vigour but is also highly significant. Therefore in addition to hybrid vigour effects, the way a cross is made between inbred sweet corn and starchy dent maize influences the cold tolerance of seeds.

(ii) Reciprocal Differences. The germination of four pairs of reciprocal crosses between dent maize and sweet corn are given in table 3. The endosperm in maize is triploid, i.e. there are three chromosome sets in each of its cells. Two chromosome sets are provided by the seed parent

TABLE 3

Effect of Reciprocal Crosses between Sweet Corn and Dent Maize on Cold Tolerance of Seeds

\begin{tabular}{|c|c|c|c|}
\hline${ }_{\text {Cross }} E_{n d_{\text {osperm }}}$ & $\begin{array}{c}\% \mathrm{Ger} \\
\mathrm{Su} / \mathrm{Su} / \mathrm{su}\end{array}$ & $\begin{array}{l}\text { ation } \\
\text { Su/su/su }\end{array}$ & Difference \\
\hline 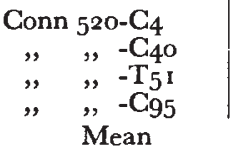 & $\begin{array}{l}71 \cdot 0 \\
90 \cdot 0 \\
98 \cdot 0 \\
85 \cdot 0 \\
86 \cdot 0\end{array}$ & $\begin{array}{l}90 \cdot 0 \\
70 \cdot 0 \\
46 \cdot 0 \\
62 \cdot 0 \\
67 \cdot 0\end{array}$ & $\begin{array}{l}-19 \cdot 0 \\
+20 \cdot 0 \\
+52^{\circ} 0 \\
+23 \cdot 0\end{array}$ \\
\hline
\end{tabular}

but one dose only comes from the pollen parent. Hence endosperms may differ genetically in reciprocal crosses according to the dominance of the genes involved. The $S u$ gene is dominant irrespective of dosage; seeds containing it are always starchy. Thus all seeds in the reciprocal crosses, even those on sweet corn ears, had starchy endosperms. Hlybrid seeds taken from dent ears, i.e. with endosperms containing two $\mathrm{Su}$ doses, were considerably more tolerant of cold than hybrid seeds from sweet ears which had only one $S u$ dose in their endosperms. There was one exception. This was Conn 520 crossed with $\mathrm{C}_{4}$; yet Haskell (r 949 ) has already shown that $\mathrm{C}_{4}$ can be more cold tolerant than Conn 520 under more prolonged treatment. Although Conn $5^{20}$ has somewhat 
higher germination than $\mathrm{C}_{4}$ in the present experiment, this exception proves valuable when considering the influence of the pericarp.

The wet weights of seedlings in reciprocal crosses are given in table 4 . Maternal effects would have been in evidence, as readings were taken

TABLE 4

Seedling Weights of Reciprocal Crosses

\begin{tabular}{|c|c|c|c|}
\hline 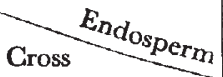 & $\begin{array}{r}\mathrm{W} \\
\mathrm{Su} / \mathrm{Su} / \mathrm{su}\end{array}$ & $\mathrm{Su} / \mathrm{su} / \mathrm{su}$ & Difference \\
\hline $\begin{array}{cl}\text { C.520-C4 } \\
\Rightarrow, & -C_{40} \\
\Rightarrow & -T_{51} \\
\Rightarrow, & -C_{95} \\
& \text { Mean }\end{array}$ & $\begin{array}{l}\mathrm{I} \cdot 57 \\
\mathrm{I} \cdot \mathrm{I} 3 \\
\mathrm{I} \cdot 20 \\
0 \cdot 64 \\
\mathrm{I} \cdot 14\end{array}$ & $\begin{array}{l}\mathbf{r} \cdot 28 \\
0 \cdot 74 \\
\mathbf{I} \cdot 39 \\
\mathrm{o} \cdot 76 \\
\mathrm{I} \cdot 04\end{array}$ & $\begin{array}{l}+0.29 \\
+0.39 \\
-0.19 \\
-0.12\end{array}$ \\
\hline
\end{tabular}

(Figures refer to mean weight in gms of seedlings weighed after 18 days in a warm greenhouse)

only eighteen days after transference to warmth. There is no indication, however, that seedlings from $S u / S u / s u$ endosperms are necessarily heavier than those from $\mathrm{Su} / \mathrm{su} / \mathrm{su}$ endosperms. Nor is there evidence in any one direction of undue influence of cytoplasmic effects from the embryo itself.

It thus seems that although there are reciprocal differences in cold tolerance of maize seeds, neither cytoplasmic influences nor dosage of the $S u$ gene are likely to be of primary importance; other factors must be acting.

(iii) Heterosis. The analysis of variance (table 2) shows that inbreds and hybrids differ significantly in germination. The means of inbred parents can therefore be compared with means of their reciprocal $F_{1}$ 's to estimate more easily the effects of hybrid vigour. These data are given in table 5. Here it is seen that most $F_{1}$ 's have higher germinations than their parental averages. The cross of Conn $5^{20}$ with $\mathrm{T}_{5} \mathrm{I}$

TABLE 5

Influence of Hybrid Vigour on Maize Cold Tolerance

\begin{tabular}{|c|c|c|c|c|}
\hline Endosperm & Cross & $\begin{array}{c}\% \text { Gern } \\
\text { Inbred Parental } \\
\text { Means }\end{array}$ & $\begin{array}{l}\text { ination } \\
\text { Reciprocal } F_{1} \\
\text { Means }\end{array}$ & Difference \\
\hline Starchy & 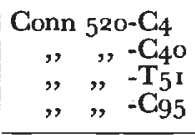 & $\begin{array}{l}77 \cdot 0 \\
76 \cdot 5 \\
72 \cdot 8 \\
47 \cdot 8\end{array}$ & $\begin{array}{l}80 \cdot 5 \\
80 \cdot 0 \\
72 \cdot 0 \\
73 \cdot 5\end{array}$ & $\begin{array}{r}+3.5 \\
+3.5 \\
-0.8 \\
+25.7 \\
\end{array}$ \\
\hline Sugary & $\begin{array}{l}\mathrm{C}_{40} \mathrm{O}-\mathrm{T}_{5 \mathrm{I}} \\
\mathrm{C}_{4}-\mathrm{C}_{4} \mathrm{o} \\
\text { Mean }\end{array}$ & $\begin{array}{l}56 \cdot 3 \\
60 \cdot 5 \\
65 \cdot 2\end{array}$ & $\begin{array}{l}26 \cdot 0 \\
95 \cdot 0 \\
71 \cdot 2\end{array}$ & $\begin{array}{l}-30.3 \\
+34.5\end{array}$ \\
\hline
\end{tabular}

shows no increase, while the $F_{1}$ is considerably lower in the sweet hybrid of $\mathrm{C}_{4} \mathrm{o}$ with $\mathrm{T}_{5} \mathrm{I}$. This might be an example of negative heterosis. Thus it may be concluded that hybrid vigour usually, but not always, promotes better cold tolerance.

The comparative germinations of inbreds and hybrids under field 
conditions in England are given in fig. I. These graphs are based upon the germination of 80 hybrid and 40 inbred American sweet corns, not necessarily related to each other. They were sown on I $3^{\text {th }}$ May 1948

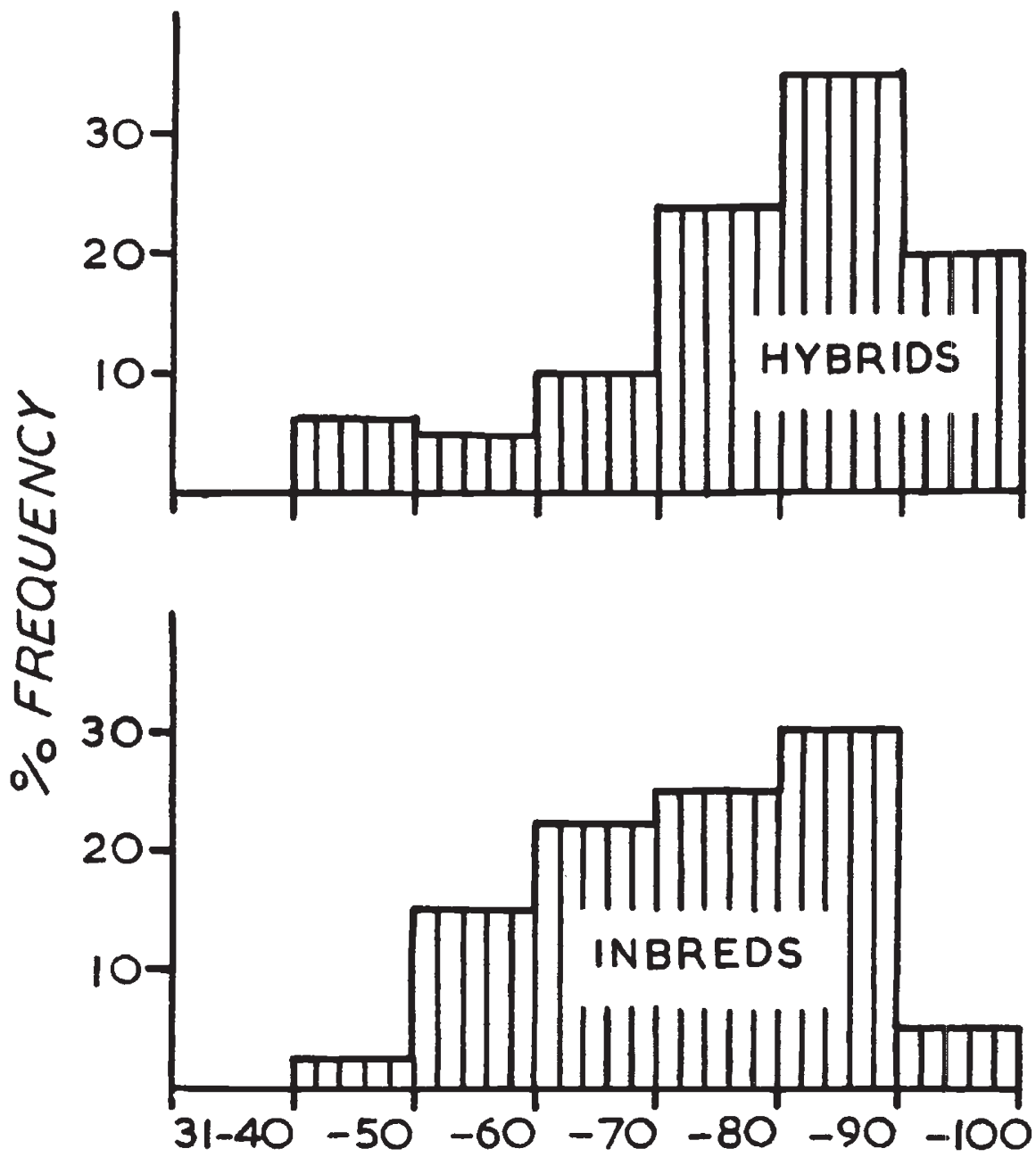

\section{GERMINATION}

FIG. I.-Percentage frequency distributions of the germinations of 40 inbred and 80 hybrid sweet corns grown at Merton, Surrey on 13 th May 1948.

at Merton, Surrey. Range of germination is similar in both types but there are comparatively more hybrids with higher germinations.

The effects of gradual inbreeding are given in table 6. Openpollinated varieties of sweet corn which had been self-pollinated for one or more generations are grouped according to their stage of inbreeding. It is readily seen that germination falls off with advances 
TABLE 6

Influence of Inbreeding on Germination of Sweet Corn under Early Field Conditions in England

$\begin{array}{ccc}\begin{array}{c}\text { Generation of } \\ \text { Inbreeding }\end{array} & \begin{array}{c}\text { No. of } \\ \text { lines }\end{array} & \text { Mean \% Germination } \\ \text { I } & 34 & 36.6 \\ 2 & 16 & 15 \cdot 1 \\ 3 \text { or more } & 35 & 10.9\end{array}$

(40 seeds per row sown 2oth April 1951)

in inbreeding, even though only better germinating lines are used as parents for the next stage of inbreeding. However, some of the decrease is no doubt due in the first stages to production of homozygous lethals. Thus inbreeding brings about reduced tolerance to cold conditions during germination. This may be due to actual loss of vigour, or to the resulting homozygosity of genes controlling reaction to disease, or to failure of inbreds to adapt themselves to difficult environmental conditions.

\section{DISCUSSION}

The genetical control of cold tolerance in sweet corn is already recognised, because it has bcen possible gradually to improve germination under English sowing conditions by breeding only from plants in better germinating lines. A diagram was given by Haskell (1948) showing the improvement in germination resulting from selection for this property. Response to selection must therefore be polygenically controlled, i.e. due to the effects of many genes acting quantitatively. Thus in this experiment it was not unexpected that lines differ in cold tolerance. Haber (1938) has already found that inbred strains of sweet corn in America differ in resistance to heat and drought. Heyne and Brunson (1940) have attributed susceptibility to heat to direct pleiotropic action of the $s u$ gene: hence the same gene might also be expected to influence cold tolerance. Hybrid vigour, maternal cytoplasmic influences and pericarp differences of seeds might also be important in promoting germination at low temperatures besides endosperm differences due to the $S u-s u$ relation. These possible influences must now be examined.

From crossing sweet and dent corns, Kiesselbach ( I 926) found that although sometimes seed weights decrease, they usually increase. There is thus not always an effect due to change in endosperm constitution. Hybrid vigour shows mostly as increased weights of seed, embryo, endosperm and perhaps pericarp, varying according to the cross. Embryos tend to increase somewhat more than endosperms, but pericarps increase far less, if at all, probably because they are maternal tissue and only indirectly influenced by the pollen parent. (Sweet $\times$ dent) give considerably higher heterotic effect than (dent $\times$ sweet), which show no change in seed weight. Yet (dent $\times$ sweet) seeds generally have better tolerance in the present experiment. Hence the improved germination of $F_{1}$ seeds cannot wholly be duc to heterosis. 
Besides heterotic effects, change in endosperm composition can itself cause marked increase in seed weight when sweets and dents are hybridised. However, pericarp weight is unaffected in sweet corn crosses which show heterosis, and only very slightly in sweet-dent crosses. The main physical differences between sweet corn and dent seeds is that sugary seeds have higher moisture content than dents, as shown by $F_{1}$ crosses. According to Kiesselbach ( $194^{8}$ ) they differ chemically mainly in having more water-soluble polysaccharides. Johann (r935) maintained that disease resistance of germinating maize seeds is bound up with chemical rather than with anatomical differences. These, even with regard to hilum openings, would not account for differences of susceptibility to Diplodia in the field. Yet better quality commercial sweet corns characteristically have reasonably tender pericarps: plant breeders have doubtless selected for thinner pericarps. Hence if thinner pericarps permit pathogens to enter more readily, or enzymes to leach out faster, sweet corn seeds will tend to be less tolerant than those of dents. This would have helped to give rise to the prevailing view that sweet corn seeds are not so hardy as those of other kinds of maize. Segregations of genetically similar starchy and sugary seeds on the same ears should therefore have similar cold tolerance and this has been observed by Haskell and Singleton (1949). Such seeds would have similar tolerances, regardless of their endosperms' genetical constitution, because the pericarps are all of maternal constitution, dent in this instance.

The above experiment supports previous work on hybrid vigour. One of the genetical aspects influencing tolerance of maize seeds to cold wet soil is whether they are heterozygous or homozygous. Maize is an outbreeding species carrying genes for disease resistance or susceptibility in a heterozygous condition. Inbreeding unmasks these genes releasing highly susceptible lines, yet at the same time permitting selection of more resistant lines. So-called homozygous, uniform, inbred lines usually have some seedlings killed off but not others. This may be due partly to differences in soil and other environmental conditions, as emphasised by Pinnell (1949), and partly to cryptic variation within the lines. This is masked to the ordinary eye, but manifests itself when the strains are faced with environmental conditions which select out the individuals genetically more adaptable to them.

In open-pollinated maize populations the paired chromosomes carry most of their genes in a heterozygous state. The cytoplasm has thus become adapted to this internal relation expected in an out-breeding species. Hence the reaction of the same cytoplasm to homozygous chromosomes found in inbreds might in effect reduce the general viability. This would establish a state of physiological unbalance in the cellular metabolism. Hence unfavourable environmental conditions react more readily on homozygous inbred lines than on balanced openpollinated varieties or heterozygotes, i.e. $\mathrm{F}_{1}$ hybrids where the state of unbalance has been restored. This has already been observed in other 
quantitative characters of maize, such as variation in height and silking dates (Haskell, r953). That inbreeding is itself injurious is shown by the gradual reduction in germinations with progressive stages of inbreeding. Major recessive lethal genes are rapidly eliminated at the first or second stage, but these would still not sufficiently account for continual decrease with continued inbreeding.

Inbreds are therefore less likely to germinate as well as hybrids under poor conditions, even when lethals have been removed. This has to be taken into account when introducing a new American hybrid into England after suitable testing. Its inbred parents may not be so adaptable and may germinate only with difficulty under the same sowing conditions. Hence it might sometimes be feasible to grow inbreds, both for stock and hybrid seed, in more suitable parts of the Commonwealth. This would not, however, alter the suitability of the hybrid to English sowing conditions, provided that the seed is correctly harvested, dried and stored.

\section{SUMMARY}

I. Germinations of inbred sweet corns, dent maize, and their reciprocal hybrids were studied following treatment in soil kept for to days at $50^{\circ} \mathrm{F}$. (10 $0^{\circ}$. ). Strains differ in cold tolerances. Inbreds generally have lower germinations than hybrids, attributed to physiological consequences of inbreeding.

2. Hybrids between sugary $(s u)$ and starchy $(S u)$ corn germinate better from a starchy mother plant. This is probably due to the excessive permeability of sweet corn pericarp which has been selected for tenderness.

3. Hybrids with improved earliness and corresponding cold tolerance could be introduced in England although their inbred line parents might have to be raised abroad.

Acknowledgment.-Thanks are due to Dr W. R. Singleton for kindly providing the Connecticut inbreds.

\section{REFERENCES}

HABER, E. S. 1938. A study of drought resistance in inbred strains of sweet corn, Zea mays, var. Rugosa. Iowa Agric. Exper. Sta. Res. Bull., 243.

HASkElL. G. 1948. Sweet corn in England. The Fruit, The Seed and the Soil, ed. C. D. Darlington. Edinburgh : Oliver \& Boyd.

HASKELL, G. 1949. Studies with sweet corn. I. Cold treatment and germination. Plant and Soil, 2, 49-57.

haskell, G. 1953. Heterosis and adaptability. Proc. ${ }_{3}$ Int. Hort. Congr., London. (In the press.)

HASKELL, G. AND SINGLETON, W. R. 1949. Use of controlled low temperature in evaluating the cold hardiness of inbred and hybrid maize. Agron. $7 ., 44^{I}, 34-40$.

HEYNE, E. G. AND BRUNSON, A. M. I940. Genetic studies of heat and drought tolerance in maize. 7. Amer. Soc. Agron., 32, 803-814. 
JOHANN, H. 1935. The histology of the caryopsis of yellow dent corn with reference to resistance and susceptibility to kernel rots. 7. Agric. Res., 5I, 855-883.

KIEsselbach, T. A. 1926. The immediate effect of gametic relationship and of parental type upon the kernal weight of corn. Nebraska Agric. Exper. Sta., Res. Bull., 33. кIEsSELBACH, т. A. 1948. Endosperm type as a physiologic factor in corn yields. 7. Amer. Soc. Agron., 40, $216-236$.

MATHER, K., AND hASKELL, G. I949. Breeding cold hardy sweet corn in Britain. $\mathcal{F}$. Agric. Sci., 39, 56-63.

MORTIMORE, c. E. Seen in Wernham, $195 \mathbf{I}$.

PinNeli, E. L. 1949. Genetic and environmental factors affecting corn seed germination at low temperatures. Agron. F., $4^{I}, 562-568$.

rossman, E. c. 1949. Freezing injury of inbred and hybrid maize seed. Agron. F., $4^{I}$, $574-583$.

RUSH, G. E. Seen in Wernham, 1951.

SMITH, O. F. 1935. The influence of low temperature on seedling development in two inbred lines of maize. 7. Amer. Soc. Agron., 27, 467-479.

WERNhAM, c. c. 195I. Cold testing of corn: a chronological and critical review. Penn. Agric. Exper. Sta., Progress Rep., 47. 